\title{
Fading Attraction of the Shrinking City: An Empirical Study from an Urban Resource Perspective
}

\author{
Yuanping Wang ${ }^{1}$, Mu Lin ${ }^{2}$, Jingxin Gao ${ }^{3, * \mathbb{D}}$ and Zhaoyin Zhou ${ }^{1}$ \\ 1 School of Civil Engineering and Architecture, Chongqing University of Science and Technology, \\ Chongqing 401331, China; ypwang@cqust.edu.cn (Y.W.); zzy@cqust.edu.cn (Z.Z.) \\ 2 School of Marxism, Dalian University of Technology, Dalian 116024, China; linmu258@dlut.edu.cn \\ 3 School of Economics and Management, Dalian University of Technology, Dalian 116024, China \\ * Correspondence: jxin25@cqu.edu.cn
}

Citation: Wang, Y.; Lin, M.; Gao, J.; Zhou, Z. Fading Attraction of the Shrinking City: An Empirical Study from an Urban Resource Perspective. Sustainability 2021, 13, 11550. https:// doi.org/10.3390/su132011550

Academic Editors: Pierfrancesco De Paola, Francesco Tajani,

Marco Locurcio and Felicia Di Liddo

Received: 3 September 2021

Accepted: 11 October 2021

Published: 19 October 2021

Publisher's Note: MDPI stays neutral with regard to jurisdictional claims in published maps and institutional affiliations.

Copyright: (c) 2021 by the authors. Licensee MDPI, Basel, Switzerland. This article is an open access article distributed under the terms and conditions of the Creative Commons Attribution (CC BY) license (https:// creativecommons.org/licenses/by/ $4.0 /)$.

\begin{abstract}
The accelerated flow of resources and the population has resulted in the coexistence of the expansion and shrinkage of cities. The shrinking city is not a new thing, but it is a new problem that needs to be solved urgently in China. Urban resources reveal the direct cause of the shrinking city: attraction, which reflects the competition for external resources and the endowment of the intrinsic resources of cities. Therefore, this paper established the Urban Resource Degree (URD) model to measure the urban resource degree of the shrinking city. Factors were then selected to analyze the ways in which they influence the shrinking cities. Given the spillover effect and heterogeneity of the influencing factors, a Spatial Durbin Model (SDM) and a Spatiotemporal Geographically Weighted Regression Model (GTWR) were used to conduct a spatial spillover (SSA) and spatial heterogeneity (SHA) analysis of the URD of the shrinking cities in Northeast China. The results show that the ability gap to compete for and control resources between prefecture-level shrinking cities and county-level shrinking cities is narrowed. From the SSA and SHA perspectives, the influence factors can be categorized into three types: "High West-Low East and Negative-Positive Spillover", "Low West and High East Positive-Negative Spillover", "Low Northwest and High Southeast Negative Spillover". Finally, policy implications are proposed to provide support for policy-making.
\end{abstract}

Keywords: shrinking city; urban resource degree; spatial spillover analysis (SSA); spatial heterogeneity analysis (SHA); policy-making

\section{Introduction}

The shrinking city is a young, crucial issue related to human sustainably development which needs to be given more attention. It is not a new thing, but it is a new problem that needs to be solved urgently. After the industrial revolution, cities grew explosively [1]. Both the number and the size of cities have shown a rapid growth which is unprecedented in human history. Since the 1990s, the urbanization rates of the United Kingdom, the United States, Germany, and France have far exceeded 50\% [2-5]. However, at the beginning of the 20th century, some cities in these countries ended their growth process, and a series of problems such as urban population decline, economic recession, industrial imbalance, and a surge in unemployment appeared. For example, Leipzig, Germany, lost more than 100,000 people from 1951 to 1998, accounting for 20\% of the total population [6]; Liverpool, the United Kingdom, began to experience a large-scale population decline in the mid-19th century. As of 2008, its population had decreased by 49\% compared to 1931 [7]. Similar cases include the city of Hakodate in Japan, Detroit and Pittsburgh in the United States, and Leksa in Finland, etc. These cities all once flourished during the industrialization period, but they have all undergone a historic transformation from prosperity to decline.

The phenomenon of the shrinking city does not only appear in highly urbanized developed countries. In the process of large-scale urbanization, shrinking cities in China have begun to appear. China's urbanization has entered the turning point of the times, 
with large cities that cannot be contained on the one hand, and small cities that cannot be supported on the other [2]. Relevant studies have used different statistical calibers to identify and analyze shrinking cities. Due to the differences in the definition and the criteria of a shrinking city, the results obtained by related scholars are not in complete accord. After analyzing the data of the Fifth Census (2000) and the Six Census (2010), Zhang believed that more than $26 \%$ of the prefecture-cities and $37 \%$ of the county-level cities in China have experienced relative shrinking [3,4]; Long pointed out that between 2000 and 2010, 180 cities in China experienced negative population growth [5]. After analyzing the data of 663 cities in China from 2007 to 2016, Wu found that 84 cities had different degrees of shrinking [6,7]. Although the conclusions obtained by various scholars are different, it should not be ignored that these results show that the phenomenon of urban shrinkage has indeed occurred in China. Furthermore, the number and scale of the shrinking cities are still expanding.

In order to reveal the mechanism of the population loss and the series of problems, the "shrinking city" was formally proposed by scholars [8], and a few scholars have carried out in-depth research on it and achieved a series of fruitful results. As shown in Table 1, de-industrialization, suburbanization, and political system transformation have become the main reasons for the shrinking cities in European and American countries $[9,10]$.

Table 1. Influencing factors of the shrinking city.

\begin{tabular}{|c|c|c|}
\hline Author & Contents and Cases & Conclusion of Shrinking \\
\hline $\begin{array}{l}\text { C. Martinez-Fernandez et al. [11] } \\
\text { J. Kotilainen [12] } \\
\text { K. Pallagst [13] }\end{array}$ & $\begin{array}{l}\text { Yubari, Japan } \\
\text { Lieksa, Finland } \\
\text { Flint, Michigan }\end{array}$ & $\begin{array}{l}\text { Resource depletion, single industrial structure, } \\
\text { natural disasters and environmental pollution }\end{array}$ \\
\hline $\begin{array}{c}\text { C. Freixas et al. [14] } \\
\text { D. Camarda [15] } \\
\text { C. Martinezfernandez [16] }\end{array}$ & $\begin{array}{c}\text { St. Louis, USA } \\
\text { Taranto, Italy } \\
30 \text { cities around globe }\end{array}$ & $\begin{array}{l}\text { Deindustrialization, suburbanization and } \\
\text { white people living in the suburbs for fear of } \\
\text { public security in the city center (white flight) }\end{array}$ \\
\hline $\begin{array}{l}\text { R. Howe Steven [17] } \\
\text { K. Pallagst [13] }\end{array}$ & $\begin{array}{c}\text { Cincinnati, Cleveland, Dayton, and } \\
\text { Youngstown, Ohio } \\
\text { Flint, Michigan, USA }\end{array}$ & $\begin{array}{l}\text { Suburbanization, regional transportation } \\
\text { system promotion and restriction, regional } \\
\text { unbalanced development, urban sprawl }\end{array}$ \\
\hline $\begin{array}{l}\text { T. Wiechmann [18] } \\
\text { C. Cortese [19] } \\
\text { T. Panagopoulos [20] }\end{array}$ & $\begin{array}{c}\text { Schwedt and Dresden, Germany; } \\
\text { Youngstown and Pittsburgh, USA } \\
\text { Ostrava, Czech Republic; Génova, Itália e } \\
\text { Leipzig, Alemanha } \\
\text { Portuguese }\end{array}$ & $\begin{array}{c}\text { The birth rate, population emigration rate, } \\
\text { population density, total population and } \\
\text { population structure change }\end{array}$ \\
\hline Dga B [21] & $\begin{array}{l}\text { Shaanxi-Gansu-Ningxia region, the } \\
\text { Sichuan-Chongqing region, and the middle } \\
\text { and lower reaches of the Yangtze River }\end{array}$ & population change rate \\
\hline $\begin{array}{l}\text { B. Hollander J [22] } \\
\text { M. Bontje [23] } \\
\text { D. Haase [24] } \\
\text { A. Haase [25] } \\
\text { M. Bernt [26] }\end{array}$ & $\begin{array}{l}\text { Detroit, USA } \\
\text { Germany } \\
\text { Leipizig } \\
\text { Halle } \\
\text { Bytom }\end{array}$ & $\begin{array}{l}\text { Social equity, policy system, system } \\
\text { reform, ideology }\end{array}$ \\
\hline A. Mallach [27] & Germany, Japan and the United States & conditions, discourse, policy and action \\
\hline X. Meng [28] & 5004 shrinking cities worldwide & $\begin{array}{l}\text { population loss, economic decline, and decay } \\
\text { in spatial quality }\end{array}$ \\
\hline I. Kantor [29] & Bytom, Poland & city's policy, socio-economic situation \\
\hline M. Rocak [30] & Netherlands & $\begin{array}{l}\text { social aspects(resources, empowerment and } \\
\text { participation) }\end{array}$ \\
\hline A. Wichowska [31] & Poland & $\begin{array}{l}\text { population decline, economic decline and the } \\
\text { number of vacant homes }\end{array}$ \\
\hline
\end{tabular}


Due to the late start of urbanization in China, the shrinking city mainly occured in the 21st century, with the data explosion and rapid development of science and technology. Therefore, the phenomenon of the shrinking city in China not only has similar incentives to the developed countries but also has its unique side. The continuous construction and improvement of infrastructures such as transportation networks and telecommunications have greatly increased the flow of the population and resources in China. Besides this, many cities have abolished household registration restrictions, and some cities have provided excellent talent introduction policies to attract talents. The weakening and canceling of the restriction policy and the establishment and strengthening of the encouragement policy are gradually breaking the shackles of the population flow in China. According to China's national census data, in 2010, 261 million people left their registered places for more than half a year, with $82 \%$ of the total migrants being in eastern cities and $18 \%$ in being in central and western cities. Since the 21st century, China's population migration has become larger, faster and more frequent.

Urbanization is the process of population and resource agglomeration. In the urbanization process, some cities continue to expand, while others shrink. City shrinkage has many causes, such as economic development, climate, location, political factors and so on [32]. However, to sum up, the final reason is the city's decreased attraction. The gathering of resources accelerates the gathering of the population, and the value creation and consumption demand of the population gathering further promote the re-distribution of resources. Cities with strong "attraction" tend to gather a lot of excellent resources and become the inflow places of population, while cities with weak "attraction" naturally become outflow places. Therefore, we proposed the hypothesis that urban resources are a combination of the ability of cities to compete for external resources and the reflection of the endowment of urban resources. The level of urban resources is closely related to urban shrinkage. The level of urban resources determines the attractiveness of the city, reflecting the direct cause of urban shrinkage. However, few pieces of literature conducted an in-depth analysis of the shrinking city from the urban resource perspective. The objectives in this study are therefore to: (1) establish the URD model to measure the urban resource degree, and (2) to select factors to analyze how they influence the shrinking cities. Given the spillover effect and heterogeneity of the influencing factors, SDM and GTWR were used to conduct a spatial spillover (SSM) and spatial heterogeneity (SHM) analysis of the URD of shrinking cities in northeast China. Finally, policy implications are proposed to provide supports for policy-making.

\section{Urban Resource Degree (URD) of the Shrinking Cities}

\subsection{Methodology}

URD is the synthesis metric of the city's ability to compete for external resources and the resource endowment. Here, the resource is a general concept involving all of the tangible and intangible necessities for urban development, such as land, water, labor, culture, policy, and so on. Previous pieces of literature have focused on the URD from the perspectives of urban competitiveness [33-37] and sustainability development [38-42]. Although these focuses can reflect the URD to some degree, they are more comprehensive conceptual frameworks which are not limited to the URD. Therefore, they cannot be used to analyze URD accurately and pertinently. Besides this, some scholars have conducted an in-depth analysis of the resources between different cities [43-47] and different industries [48-51] in urban agglomeration through the gravity model. The gravity model can reflect the resource competence ability of two cities exactly, but cannot reflect the resource competence ability of one city compared to all other cities. From the concept of URD, it can be said that industrial agglomeration is the external performance of URD, and URD is the internal motivation of urban industrial agglomeration. Therefore, this paper proposed a weighted comprehensive industrial agglomeration model (WCIA) to measure the city's URD. The WCIA is as follows:

$$
\text { Spatial Gini coefficient }
$$




$$
G_{i}=\sum_{j=1}^{n} G_{i j}=\sum_{j=1}^{n}\left(x_{j}-s_{i j}\right)^{2}
$$

$G_{i}$ is the total Gini coefficient of industry $i ; G_{i j}$ is the Gini coefficient of industry $i$ in city $j ; x_{j}$ is the percentage of the total employment in city $j$ compared to the total employment in an urban agglomeration. $S_{i j}$ is the ratio of industry $i$ in city $j$ to the total employment of industry $i$ in an urban agglomeration. $G_{i}=1$ indicates that the industrial agglomeration degree is high. Otherwise, $G_{i}=0$ shows that the industrial distribution is balanced.

(2) Weight assignment

Suppose that there is an industry set of city $i E_{i}=\left\{e_{i 1}, e_{i 2}, \cdots e_{i m}\right\}$ The Gini coefficient of industry $j$ in city $i$ at time $t$ is recorded as $x_{t i j}=(t=1,2, \cdots T ; i=1,2, \cdots m)$. The decision sets are as follows:

$$
X_{t}=\left[\begin{array}{ccc}
x_{t 11} & \cdots & x_{t 1 m} \\
\vdots & \ddots & \vdots \\
x_{t n 1} & \cdots & x_{t n m}
\end{array}\right]
$$

According to the numerical properties of $x_{t i j}$, it can be divided into the positive index and negative index. In this paper, the range transformation method is used to normalize the positive index and negative index.

$$
\begin{aligned}
& v_{t i j}^{+}=\frac{x_{t i j}-\min \left(x_{j}\right)}{\max \left(x_{j}\right)-\min \left(x_{j}\right)} \\
& v_{t i j}^{-}=\frac{\max \left(x_{j}\right)-x_{t i j}}{\max \left(x_{j}\right)-\min \left(x_{j}\right)}
\end{aligned}
$$

$v_{t i j}^{+}$and $v_{t i j}^{-}$are the positive normalization index and negative normalization index, respectively. $\max \left(x_{j}\right)$ and $\min \left(x_{j}\right)$ are the maximum and minimum values of the $j$-th index. The weight of industry $j$ of the city $i$ in time $t$ is

$$
P_{t i j}=\frac{v_{t i j}}{\sum_{j=1}^{n} v_{t i j}}
$$

where $0 \leq v_{t i j} \leq 1 ; 0 \leq P_{t i j} \leq 1$. The entropy of industry $j$ in time $t$ is

$$
e_{t j}=-\left(1 / L_{n} n\right) \sum_{i=1}^{n} P_{t i j} L_{n}\left(P_{t i j}\right)
$$

The weight of the Gini coefficient of industry $j$ in time $t$ is

$$
w_{t j}=\left(1-e_{t j}\right) / \sum_{k=1}^{n}\left(1-e_{k}\right)
$$

(3) Urban resource degree (URD)

This paper combines the level of industrial agglomeration to form the overall concept of urban resources to reflect the city's resource endowment and its ability to compete 
for external resources. In Equation (8), $N_{i}$ is the URD of city $i$ at time $t ; G_{t i j}$ is the Gini coefficient of industry $i$ in city $j$ at time $t$.

$$
N_{t i}=\sum_{j=1}^{n} w_{t j} G_{t i j}
$$

\subsection{Materials and Indicators Selection}

The Shrinking City International Research Network (SCIRN) formally defined urban shrinkage as a city that has at least 10,000 residents, has experienced negative population growth for more than 2 years, and has undergone some structural crisis in economic structural transformation [52]. Since then, relevant research focused on urban shrinkage has achieved fruitful results. Oswalt defines urban shrinkage as cities that will lose a large number of residents, and stipulates that the annual population loss rate should be more than 1\% [53]. After the establishment of the "China Shrinking Cities Research Network", scholars have systematically combed and summarized previous research and analyzed the development status of urban shrinkage in China. Zhang [54] and Long et al. [55] measured China's urban shrinkage through the data of the two national censuses in 2000 and 2010. Meanwhile, Zhang et al. judged China's shrinking cities as "one body, two wings and three dimensions" based on remote sensing data and geospatial data [56]. Liu et al. analyzed shrinking cities based on night light data [57].

Here, we can know that the academic community has not yet reached a consensus on the criteria for the determination of urban shrinkage, but the generally agreed upon view is that the decrease in the urban population is the core feature of shrinking cities. Professor Wu Kang of Capital University of Economics and Trade comprehensively interpreted the definition of the shrinking city, and based on the urban population data of municipalities directly under the central government, provincial capital cities, prefecture-level cities and county-level cities from 2007 to 2016, the cities with a lower population in 2016 than in 2007 and negative population growth in three consecutive natural years were identified [58]. Results showed that 80 out of 660 cities meet the criteria for shrinking cities.

There are 24 shrinking cities (see Table 2) in the three provinces of Northeast China, accounting for $30 \%$ of the total shrinking cities. The three provinces in Northeast China are an old industrial base in China. In the 1930s, the most advanced industrial system in Northeast Asia was built, which once occupied 98\% of China's heavy industrial base. In recent years, there has been a slowdown in the speed of economic development and the phenomenon of population outflow, resulting in a large number of shrinking cities. Northeast China is an important industrial agglomeration and economic development pioneer in China. However, there is a lot of urban shrinkage in these areas. It is worth exploring the deep-seated reasons for this phenomenon. Therefore, 24 shrinking cities in Northeast China were taken as research objects, and the URD was measured.

Table 2. Shrinking cities selected in Northeast China.

\begin{tabular}{cccccccc}
\hline Code & City & Code & City & Code & City & Code & City \\
\hline R1 & Anshan & R7 & Bei'an & R13 & Fuxin & R19 & Ningan \\
R2 & Fushun & R8 & Nehe & R14 & Jixi & R20 & Jiamusi \\
R3 & Qiqihar & R9 & Tumen & R15 & Beipiao & R21 & Hegang \\
R4 & Zhaodong & R10 & Jinzhou & R16 & Shulan & R22 & Baishan \\
R5 & Haicheng & R11 & Yingkou & R17 & Hailin & R23 & Fujin \\
R6 & Huadian & R12 & Tonghua & R18 & Ji'an & R24 & Daqing \\
\hline
\end{tabular}

Data source: https: / finance.sina.com.cn/china/gncj/2019-04-10/doc-ihvhiqax1466676.shtml (accessed on 1 october 2021). 


\subsection{Data Source}

In China, there are 20 industry categories, 97 major categories, 473 medium categories and $1380 \mathrm{sub}$ categories according to the National Economic Industry Classification Standard compiled by the National Bureau of Statistics. Given the research's purpose and operability, data-accessible, resource-intensive industries were selected as the sector indicators to measure the urban resource degree. Only the agglomeration of high-tech, high valueadded and resource-intensive industries can truly reflect the level of urban resources. To reflect the URD of cities, we selected the manufacturing industry; mining industry; scientific research and technical service industry; information transmission, software and information technology service industry; and financial industry. The relevant data are from China Statistical Yearbook, China Urban Statistical Yearbook, China Urban Construction Statistical Yearbook, China Energy Statistical Yearbook, and the Urban Statistical Yearbook, the regional statistical bulletin, and some network data from some provinces, municipalities, prefecture-level cities and county-level cities.

\subsection{Urban Resource Degree (URD)}

The URD of 24 cities in Northeast China from 2007 to 2016 is listed in Table 3.

Table 3. The URD of 24 cities in Northeast China from 2007 to 2016.

\begin{tabular}{|c|c|c|c|c|c|c|c|c|c|c|c|}
\hline $\begin{array}{ll}\text { City } \\
\text { Province }\end{array}$ & Region & 2007 & 2008 & 2009 & 2010 & 2011 & 2012 & 2013 & 2014 & 2015 & 2016 \\
\hline \multicolumn{12}{|l|}{ Liaoning } \\
\hline Anshan & West & 0.471 & 0.588 & 0.367 & 0.431 & 0.473 & 0.559 & 0.310 & 0.602 & 0.491 & 0.482 \\
\hline Beipiao & West & 0.099 & 0.108 & 0.002 & 0.059 & 0.084 & 0.120 & 0.155 & 0.142 & 0.123 & 0.050 \\
\hline Fuxin & West & 0.152 & 0.174 & 0.103 & 0.182 & 0.166 & 0.259 & 0.108 & 0.211 & 0.106 & 0.102 \\
\hline Fushun & West & 0.395 & 0.473 & 0.300 & 0.389 & 0.468 & 0.550 & 0.160 & 0.501 & 0.326 & 0.321 \\
\hline Haicheng & West & 0.256 & 0.257 & 0.047 & 0.300 & 0.374 & 0.407 & 0.564 & 0.586 & 0.473 & 0.162 \\
\hline Jinzhou & West & 0.213 & 0.244 & 0.136 & 0.245 & 0.224 & 0.333 & 0.155 & 0.421 & 0.201 & 0.195 \\
\hline $\begin{array}{l}\text { Yingkou } \\
\text { Jilin }\end{array}$ & South & 0.387 & 0.488 & 0.416 & 0.526 & 0.667 & 0.568 & 0.238 & 0.630 & 0.476 & 0.465 \\
\hline Baishan & South & 0.193 & 0.313 & 0.146 & 0.114 & 0.103 & 0.193 & 0.052 & 0.122 & 0.123 & 0.120 \\
\hline Huadian & South & 0.073 & 0.098 & 0.026 & 0.158 & 0.123 & 0.124 & 0.156 & 0.162 & 0.114 & 0.106 \\
\hline Ji'an & East & 0.034 & 0.069 & 0.019 & 0.082 & 0.075 & 0.099 & 0.108 & 0.102 & 0.115 & 0.109 \\
\hline Shulan & North & 0.109 & 0.112 & 0.014 & 0.100 & 0.102 & 0.100 & 0.124 & 0.139 & 0.105 & 0.062 \\
\hline Tonghua & South & 0.211 & 0.245 & 0.127 & 0.122 & 0.131 & 0.146 & 0.074 & 0.170 & 0.118 & 0.077 \\
\hline Tumen & East & 0.076 & 0.077 & 0.024 & 0.037 & 0.042 & 0.041 & 0.060 & 0.065 & 0.064 & 0.070 \\
\hline \multicolumn{12}{|l|}{ Heilongjiang } \\
\hline Bei'an & North & 0.111 & 0.109 & 0.025 & 0.087 & 0.076 & 0.121 & 0.150 & 0.160 & 0.175 & 0.188 \\
\hline Daqing & West & 0.772 & 0.944 & 0.554 & 0.701 & 0.709 & 0.873 & 0.310 & 0.652 & 0.389 & 0.379 \\
\hline Fujin & East & 0.010 & 0.072 & 0.011 & 0.049 & 0.057 & 0.090 & 0.101 & 0.093 & 0.093 & 0.108 \\
\hline Hegang & North & 0.168 & 0.189 & 0.075 & 0.104 & 0.101 & 0.132 & 0.032 & 0.070 & 0.082 & 0.079 \\
\hline Hailin & South & 0.052 & 0.078 & 0.036 & 0.094 & 0.101 & 0.135 & 0.165 & 0.181 & 0.190 & 0.212 \\
\hline Jixi & East & 0.215 & 0.225 & 0.082 & 0.105 & 0.125 & 0.156 & 0.046 & 0.107 & 0.132 & 0.121 \\
\hline Jiamusi & North & 0.193 & 0.229 & 0.065 & 0.083 & 0.094 & 0.121 & 0.078 & 0.165 & 0.164 & 0.159 \\
\hline Nehe & West & 0.049 & 0.056 & 0.019 & 0.060 & 0.059 & 0.055 & 0.074 & 0.081 & 0.093 & 0.110 \\
\hline Ningan & South & 0.105 & 0.109 & 0.005 & 0.022 & 0.047 & 0.057 & 0.062 & 0.064 & 0.091 & 0.094 \\
\hline Qiqihar & West & 0.278 & 0.325 & 0.155 & 0.213 & 0.248 & 0.313 & 0.121 & 0.267 & 0.196 & 0.229 \\
\hline Zhaodong & South & 0.074 & 0.069 & 0.003 & 0.064 & 0.093 & 0.129 & 0.148 & 0.149 & 0.145 & 0.164 \\
\hline
\end{tabular}

From Figure 1, the overall performance of the URD in Liaoning province is in the state of being basically stable, with a small fluctuation from 2007 to 2016 . For the five prefecture-level cities, the URD of Fuxin was at a low level from 2007 to 2016, with a small fluctuation between 0.1 and 0.26. Besides this, Jinzhou's URD also remained at a low level. Except for 0.33 in 2012 and 0.42 in 2014, the other years were below 0.3. The URD of Fushun decreased significantly in 2013, and remained around 0.4 in the other years. After the comparison of 2007 to 2016, the overall performance of Fuxin, Jinzhou and Fushun's URD declined slightly in the past ten years. Instead, the URD of Anshan and Yingkou 
was kept above 0.4, except in 2013, and presented a slight increase in the period. The URD of the only two county-level cities, Haicheng and Beipiao, of the seven shrinking cities in Liaoning Province changed greatly from 2007 to 2016. The URD of Haicheng experienced a great decline, a sharp rise, and then a substantial decline change: the URD of Haicheng (1) decreased from 0.256 to 0.047 in 2007-2009; (2) increased from 0.047 to 0.586 in 2009-2014; and (3) decreased from 0.586 to 0.162 in 2016. In contrast, the URD of another county-level city, Beipiao, was always the lowest in the seven shrinking cities in Liaoning Province. The changes of the URD are shown in Figures 2-4.

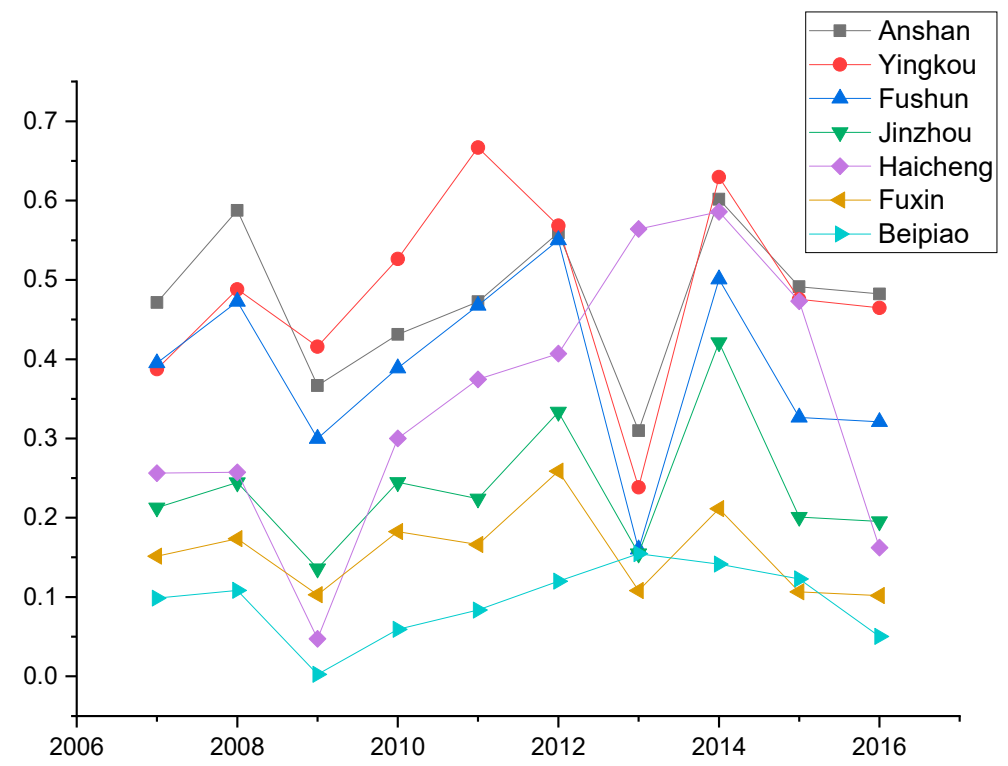

Figure 1. Changes of the URD of the shrinking cities in Liaoning.

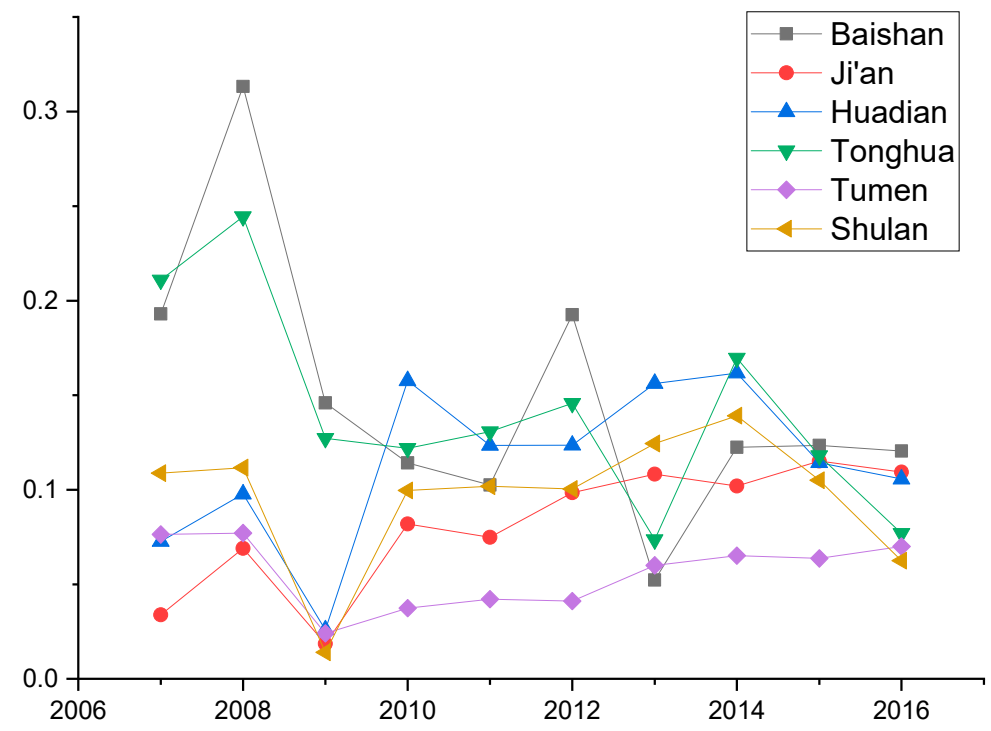

Figure 2. Changes of the URD of the shrinking cities in Jilin. 


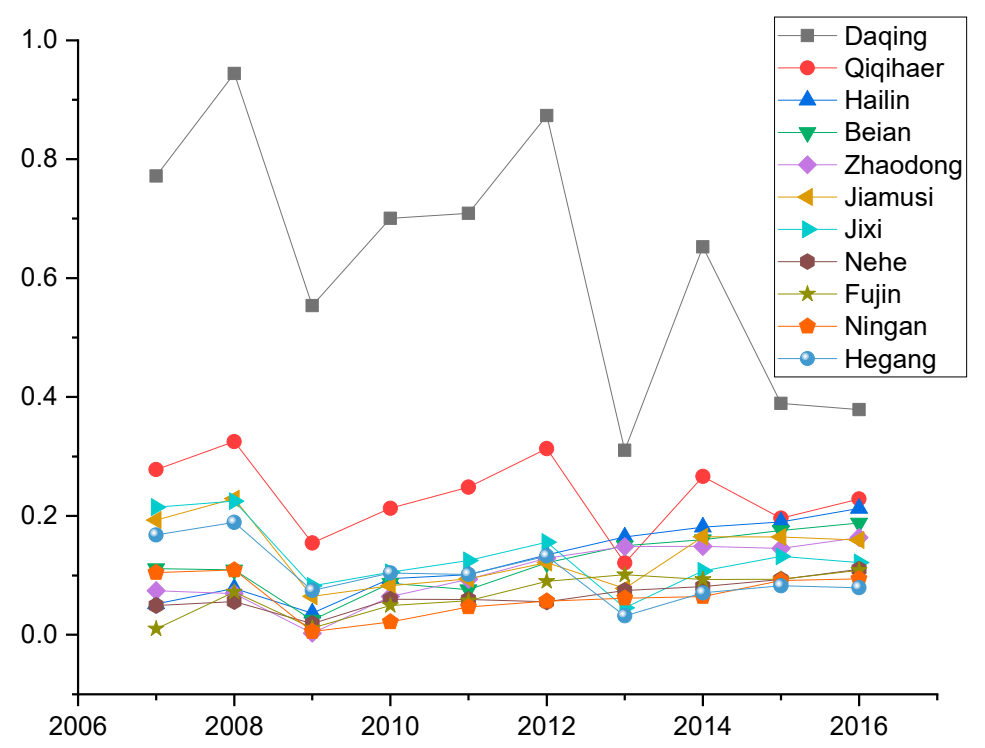

Figure 3. Changes of the URD of the shrinking cities in Heilongjiang.

From Table 3, the URD in Liaoning shows a trend of rising first and then decreasing. The resource degree of the cities in Jilin and Heilongjiang fluctuates slightly at a relatively low level.

Figure 2 illustrates the changes of the URD in the six shrinking cities in Jilin. Although the URD changes in the six cities are different, the differences are gradually narrowing and tending to converge. It is worth noting that the six shrinking cities were in a state of less than 0.2, except for Tonghua and Baishan in 2008. Tonghua and Baishan are the only two prefecture-level cities of the six shrinking cities in Jilin. As shown in Figure 3, the URD of Tonghua and Baishan were at high levels from 2007 to 2009, which were much higher than those of the other cities in the period. The URD of the two cities reached peaks which were 0.313 and 0.245 , respectively. However, after 2009, compared with other shrinking cities, the URD of Tonghua and Baishan no longer existed. In 2016, the URD of the two cities was 0.077 and 0.120 , respectively, and the difference with other cities almost disappeared. As for Huadian, Shulan, Ji'an and Tumen, the URD of the four county-level cities was less than that of the two prefecture-level cities. As of 2016, the URDs of Ji'an and Huadian were 0.109 and 0.106 , which increased by 0.076 and 0.033 , compared with 0.034 and 0.073 in 2007 . However, the URD of Tumen and Shulan decreased from 0.076 and 0.109 in 2007 to 0.07 and 0.062 in 2016, respectively.

In conclusion, the URD of the six shrinking cities in Jilin Province had a short-term upward fluctuation from 2007 to 2016, but the overall trend was downward. Besides this, the gap of the URD between the prefecture-level city and county-level city gradually narrowed. Tonghua and Baishan lost the advantages brought by their administrative levels.

In Figure 3, there are six county-level cities and five prefecture-level cities in Heilongjiang Province. Notably, although it has decreased over the years, the URD of Daqing is far higher than that of other shrinking cities in Heilongjiang Province. Besides this, the URD of other prefecture-level shrinking cities, e.g., Jixi, Jiamusi, Qiqihar and Hegang, had different changes in the periods. The URD of Qiqihar was between 0.2 and 0.33 , and ranks the second among 11 cities, only next to that of Daqing. Unlike that of Daqing and Qiqihar, the URD of Jixi and Jiamusi fluctuated slightly from 0.08 to 0.22 , and always ranked the third to sixth among the 11 cities. Besides this, the URD of the final prefecture-level shrinking city, Hegang, declined sharply after 2013, and was the last in the 11 shrinking cities in 2013, 2015 and 2016. Compared with the prefecture-level cities, the URD of the six county-level cities of Hailin, Bei'an, Zhaodong, Fujin, Nehe, and Ning'an were all ranked behind the five prefecture-level cities before 2012. However, after 2013, the URD of 
Hailin, Bei'an and Zhaodong increased significantly, and they always ranked second to sixth among the 11 cities.

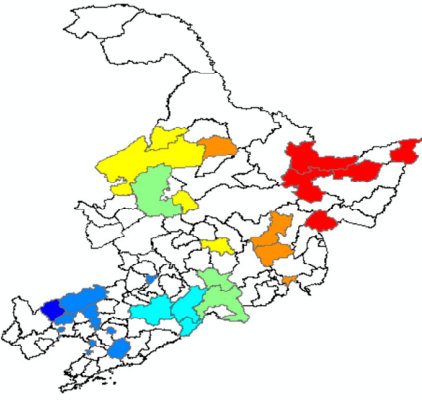

TIA

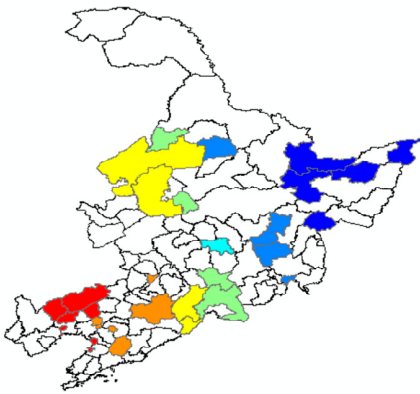

PSC

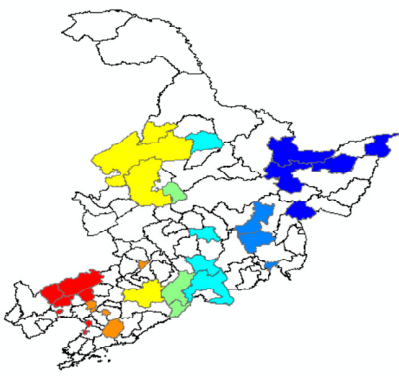

HCD

$0.0001-0.2000$

$0.2001-0.4000$

$0.4001-0.6000$

0.6001- 0.8000

$0.8001-1.0000$

1.0001-1.2000

1.2001-1.4000

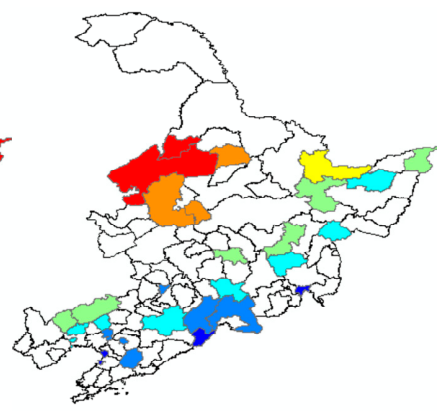

GML

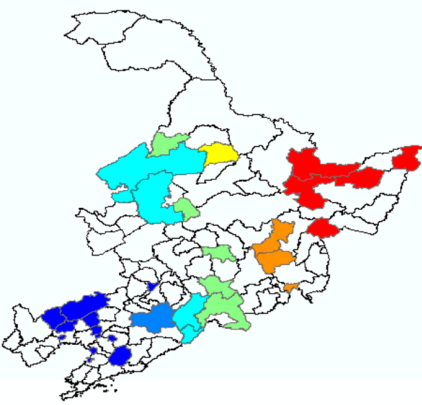

US

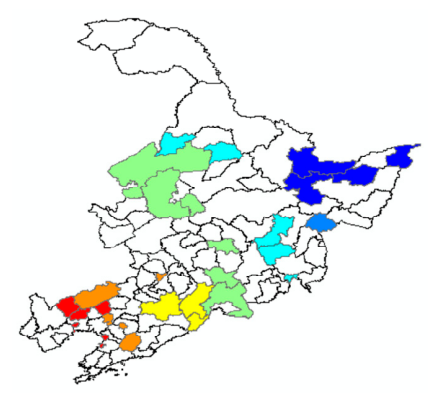

MCQ

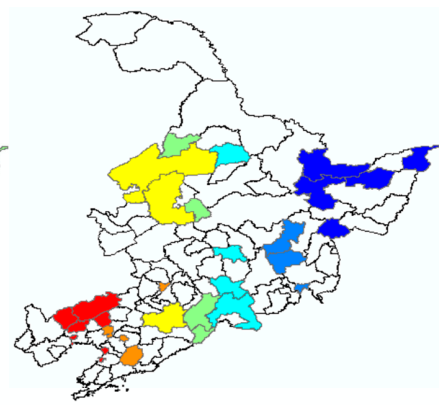

EDL

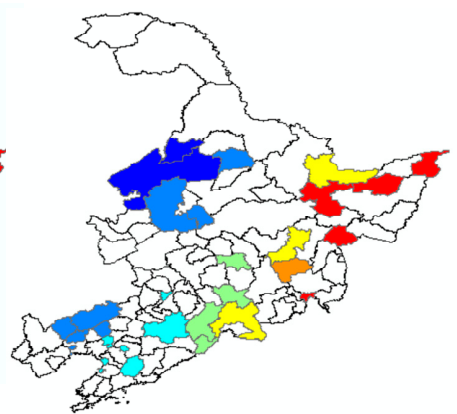

EL

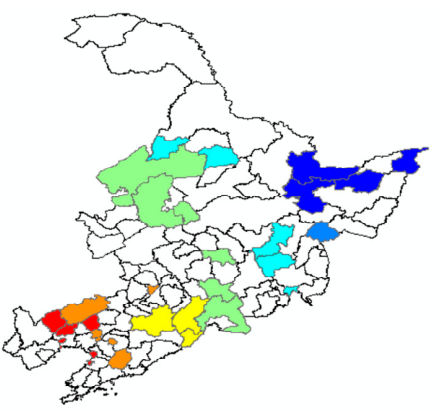

EDQ

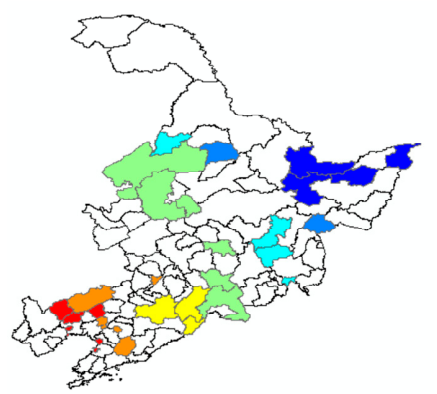

RE

Figure 4. Spatial heterogeneity of the factors' influences on URD.

In summary, over time, the advantage of the URD of prefecture-level cities gradually weakened. On the contrary, the URD in county-level cities increased slightly, and the ability of cities to compete for and control resources increased. 


\section{Factors That Influence the URD and how, from the Spatial Spillover and Spatial Heterogeneity Perspectives}

\subsection{Influence Factors}

In order to reflect various points of the previous pieces of literature from different perspectives, this paper conducted a literature review to extract the influence factors of URD. In order to avoid multicollinearity, this paper selects factors based on representativeness and the minimalist principle. We used the Factor Analysis Method (FAM) to reduce the dimension of 29 influences in Table 4. According to the relevant experience, the selected eigenvalues of the principal components must be greater than 1 , and the cumulative variance contribution rate should be more than $80 \%$. Therefore, given the results in 2007, 2011 and 2016, the top 10 principal components with cumulative variance contribution rates of $83 \%, 91 \%$ and $89 \%$ were selected. The rotating component matrix of the influencing factors of URD is shown in Table 4.

Table 4. Principal component rotation matrix of the influencing factors.

\begin{tabular}{|c|c|c|c|c|c|c|c|c|c|c|}
\hline \multirow{2}{*}{ Factors } & \multicolumn{10}{|c|}{ Factor Load } \\
\hline & F1 & F2 & F3 & F4 & F5 & F6 & F7 & F8 & F9 & F10 \\
\hline $\mathrm{X} 1$ & 0.91 & -0.12 & -0.01 & 0.18 & -0.24 & -0.02 & -0.3 & -0.03 & 0.23 & 0.08 \\
\hline $\mathrm{X} 2$ & 0.84 & 0.04 & -0.29 & -0.18 & -0.22 & -0.25 & 0.18 & 0.12 & -0.05 & -0.13 \\
\hline $\mathrm{X} 3$ & -0.1 & 0.89 & -0.22 & -0.14 & -0.01 & 0.13 & 0.26 & -0.28 & 0.18 & 0.27 \\
\hline $\mathrm{X} 4$ & -0.01 & 0.78 & -0.09 & -0.03 & 0.17 & -0.28 & -0.06 & 0.08 & -0.15 & 0.09 \\
\hline X5 & 0.06 & 0.9 & 0.04 & 0.2 & 0.21 & 0.17 & -0.11 & -0.01 & 0.07 & -0.14 \\
\hline X6 & -0.08 & -0.2 & 0.88 & -0.02 & 0.02 & -0.02 & -0.1 & -0.22 & 0.05 & -0.11 \\
\hline$X 7$ & -0.02 & 0.22 & 0.92 & 0.17 & -0.09 & 0.1 & 0.3 & 0.06 & 0.1 & -0.16 \\
\hline $\mathrm{X} 8$ & -0.17 & 0.16 & 0.95 & -0.11 & 0.2 & -0.29 & 0.14 & -0.21 & 0.28 & 0.04 \\
\hline X9 & 0.25 & -0.25 & 0.29 & 0.92 & -0.21 & -0.09 & 0.18 & -0.27 & -0.22 & 0.2 \\
\hline $\mathrm{X} 10$ & -0.17 & 0.29 & -0.25 & 0.67 & -0.16 & -0.09 & 0.05 & 0.24 & 0.24 & 0.28 \\
\hline $\mathrm{X} 11$ & 0.29 & 0.1 & 0.1 & -0.19 & 0.79 & 0.17 & -0.21 & -0.08 & 0.16 & 0.03 \\
\hline $\mathrm{X} 12$ & 0.3 & 0.23 & 0.15 & 0.16 & 0.95 & 0.15 & 0.11 & -0.09 & -0.19 & 0.21 \\
\hline $\mathrm{X} 13$ & 0.08 & -0.28 & 0.09 & 0.21 & 0.88 & -0.05 & 0.19 & -0.15 & -0.16 & -0.03 \\
\hline X14 & 0.27 & -0.09 & 0.29 & 0.04 & 0.83 & 0.27 & 0.26 & 0.27 & 0.03 & -0.24 \\
\hline X15 & -0.07 & 0.11 & -0.27 & 0.28 & 0.91 & 0.08 & -0.02 & 0.17 & 0.03 & 0.06 \\
\hline X16 & 0.25 & 0.2 & 0.12 & 0.15 & 0.82 & 0.16 & -0.23 & 0.16 & -0.01 & 0.08 \\
\hline $\mathrm{X} 17$ & -0.02 & 0.12 & -0.25 & -0.24 & 0.69 & 0.08 & -0.12 & -0.27 & -0.08 & -0.13 \\
\hline X18 & 0.15 & 0.28 & -0.22 & 0.16 & 0.05 & 0.96 & -0.25 & -0.2 & 0.27 & -0.21 \\
\hline X19 & -0.13 & 0.09 & 0.04 & -0.14 & 0.24 & 0.01 & 0.89 & -0.19 & -0.17 & 0.07 \\
\hline X20 & -0.23 & -0.19 & -0.06 & 0.03 & 0.3 & 0.18 & 0.79 & -0.17 & -0.07 & 0.28 \\
\hline X21 & -0.18 & 0.11 & -0.11 & 0.08 & -0.08 & -0.17 & 0.8 & -0.18 & -0.05 & 0.01 \\
\hline$X 22$ & -0.18 & -0.09 & 0.16 & 0.27 & 0.03 & -0.13 & 0.9 & 0.109 & 0.09 & -0.16 \\
\hline X23 & -0.09 & 0.07 & 0.03 & -0.29 & 0.14 & -0.15 & 0.95 & 0.095 & 0.23 & 0.25 \\
\hline X24 & -0.21 & 0.24 & 0.24 & 0.17 & 0.13 & -0.21 & 0.74 & 0.08 & 0.09 & -0.19 \\
\hline X25 & 0.05 & 0.16 & -0.19 & -0.12 & -0.17 & -0.11 & -0.13 & 0.82 & 0.13 & -0.29 \\
\hline X26 & -0.11 & 0.23 & 0.01 & -0.21 & 0.28 & -0.26 & 0.06 & 0.21 & 0.74 & 0.09 \\
\hline X27 & -0.02 & 0.01 & 0.26 & -0.2 & -0.26 & -0.23 & 0.05 & -0.25 & 0.91 & 0.34 \\
\hline X28 & -0.11 & 0.23 & 0.23 & -0.23 & -0.12 & 0.28 & 0.13 & -0.29 & -0.17 & 0.83 \\
\hline X29 & -0.04 & 0.11 & -0.16 & 0.22 & 0.17 & -0.24 & 0.22 & -0.03 & -0.26 & 0.64 \\
\hline
\end{tabular}

Factors: X1-R\&D investment; X2-Number of patent applications; $X 3-$ Actual use of foreign capital; $\mathrm{X} 4-\mathrm{SME}$ registration application approval cycle; $\mathrm{X} 5-$ House price to income ratio; $X 6$ - GDP per capita; $X 7$-Disposable income per capita; $X 8$ - The total retail sales of social consumer goods; $X 9$-Proportion of secondary and tertiary industries; X10-Investment in the fixed assets of the whole society; X11-Amount of public transportation per 10,000 people; X12-Road mileage per capita; X13-Hydropower supply capacity; X14-Proportion of the education expenditure to financial expenditure; X15-Number of secondary schools per 10,000 people; X16-Proportion of the medical expenditure to financial expenditure; X17-Number of hospitals per 10000 people; X18Urban population density; X19-Per capita garden area; X20-Greening rate of the built-up 
area; X21-Days of reaching air standards per year; X22-Industrial SO2 treatment rate; X23 - Wastewater treatment rate; X24-Comprehensive utilization rate of solid waste; X25-Resource abundance; X26-Number of provincial cultural relic protection units per million people; $X 27-$ Number of cultural venues per capita; X28-Contributions per capita; X29-Average number of students in Colleges and universities per 10,000 people.

From Table 4, 29 influencing factors are divided into the following 10 principal components. The detailed information of the 10 principal components is listed in Table 5 .

Table 5. Factors Affecting the URD.

\begin{tabular}{|c|c|c|}
\hline Principle Indicators & Abbreviation & Indicators \\
\hline City's technological innovation ability & TIA & R\&D investment, Number of patent applications \\
\hline Government management level & GML & $\begin{array}{l}\text { Actual use of foreign capital, SME registration application } \\
\text { approval cycle, House price to income ratio }\end{array}$ \\
\hline The level of economic development & EDL & $\begin{array}{c}\text { GDP per capita, Disposable income per capita, The total retail } \\
\text { sales of social consumer goods }\end{array}$ \\
\hline Economic development quality & EDQ & $\begin{array}{c}\text { Proportion of secondary and tertiary industries, Investment in } \\
\text { fixed assets of the whole society }\end{array}$ \\
\hline Public service capability & PSC & $\begin{array}{l}\text { Number of public transportations per } 10,000 \text { people, Road } \\
\text { mileage per capita, Hydropower supply capacity, Proportion } \\
\text { of education expenditure in financial expenditure Resource } \\
\text { abundance, Number of secondary schools per } 10,000 \text { people } \\
\text { Proportion of medical expenditure in financial expenditure, } \\
\text { Number of hospitals per } 10000 \text { people }\end{array}$ \\
\hline Urban size & US & Urban population density \\
\hline Environmental level & EL & $\begin{array}{c}\text { Per capita garden area, Greening rate of built-up area, Days of } \\
\text { reaching air standard per year, Industrial SO2 treatment rate, } \\
\text { Wastewater treatment rate, Comprehensive utilization rate of } \\
\text { solid waste }\end{array}$ \\
\hline Natural resources & RE & Resource abundance \\
\hline Historical and cultural heritage & $\mathrm{HCD}$ & $\begin{array}{l}\text { Number of provincial cultural relics protection units per } \\
\text { million people, Number of cultural venues per capita }\end{array}$ \\
\hline The moral and cultural quality of residents & MCQ & $\begin{array}{l}\text { Contributions per capita, Average number of students in } \\
\text { Colleges and universities per } 10000 \text { population }\end{array}$ \\
\hline
\end{tabular}

\subsection{SSA and SHA for the Factors of URD}

To reveal the spatial spillover and spatial heterogeneity of the URD in the 24 shrinking cities, we used the Spatial Durbin Model (SDM) and Spatiotemporal Geographically Weighted Regression model (GTWR) to perform the SSA and SHA.

(1) SDM for SSA

The SDM is as follows:

$$
\begin{aligned}
& y=\rho W y+X \beta+W \bar{X} \gamma+\varepsilon \\
& \varepsilon \sim N\left(0, \delta^{2} I\right)
\end{aligned}
$$

where $\rho$ is the marginal influence of the dependent variables of adjacent regions. $\beta$ is the marginal effect of the independent variable on the dependent variable. $\gamma$ measures the marginal effects of independent variables in adjacent regions on the dependent variables. $\bar{X}$ is a variable matrix of the independent variables.

\section{(2) GTWR for SHA}

Because the data may be non-stationary in time and space, the influence of the independent variable on the dependent variable is different in different times and regions; that is, there is heterogeneity in time and space. GTWR is an extended model of Geographically Weighted Regression (GWR), which embeds the time dimension into the regression model. 
It takes into account the data changes of the URD of the shrinking cities in time and space. Therefore, GTWR is more in line with the actual situation.

$$
Y_{i}=\beta_{0}\left(\mu_{i}, v_{i}, t_{i}\right)+\sum_{k} \beta_{k}\left(\mu_{i}, v_{i}, t_{i}\right) X_{i k}+\varepsilon_{i}
$$

Here, $Y_{i}$ is the URD of city $i, \mu_{i}$ is the longitude coordinate of city $i, v_{i}$ is the latitude coordinate of city $i$, and $t_{i}$ is the time coordinate of city $i$. Therefore, $\left(\mu_{i}, v_{i}, t_{i}\right)$ is the spacetime longitude and latitude coordinates of city $i . \beta_{0}\left(\mu_{i}, v_{i}, t_{i}\right)$ is the constant term, and $\beta_{k}\left(\mu_{i}, v_{i}, t_{i}\right)$ is the independent variable regression coefficient. $X_{i k}$ is the $k$-th independent variable of city $i . \varepsilon_{i}$ is the random error. The coefficient estimation of GTWR is as follows:

$$
\begin{gathered}
\hat{\beta}\left(\mu_{i}, v_{i}, t_{i}\right)=\left[X^{T} W\left(\mu_{i}, v_{i}, t_{i}\right) X\right]^{-1} X^{T} W\left(\mu_{i}, v_{i}, t_{i}\right) Y \\
W\left(\mu_{i}, v_{i}, t_{i}\right)=\operatorname{diag}\left(W_{i 1}, W_{i 2}, \cdots W_{i n}\right) \\
W_{i j}=\exp \left[\frac{\left(d_{i j}^{S T}\right)^{2}}{h^{2}}\right]=\exp \left[\frac{\lambda\left[\left(\mu_{i}-\mu_{j}\right)^{2}-\left(v_{i}-v_{j}\right)^{2}+\mu\left(t_{i}-t_{j}\right)^{2}\right]}{h^{2}}\right]
\end{gathered}
$$

$H$ is the space-time bandwidth, which is selected according to the minimum crossvalidation $(C V)$.

$$
C V(h)=\sum_{i}\left(y_{i}-y_{l}(h)\right)^{2}
$$

\subsection{Data Source and Processing}

Part of the raw data comes from the China Statistical Yearbook, China Urban Statistical Yearbook, China Urban Construction Statistical Yearbook, China Energy Statistical Yearbook, Urban Statistical Yearbook, and some regional statistical bulletins and network data. Specifically, the R\&D investment and social electricity consumption of the prefecturelevel cities are from China's urban statistical yearbook. Instead, in 2011-2016, the R\&D investment and social electricity consumption of county-level cities are from China's urban statistical yearbook. In 2007-2010, the R\&D investment of county-level cities is from the statistical yearbook of local provinces and the relevant statistical bulletin. The social electricity consumption is from the Power Industry Statistical Data Collection, the Statistical Yearbook of local cities, and related statistical bulletins. Besides this, the raw data of the built-up area are from the China Urban Construction Statistical Yearbook and Regional Statistical Yearbook. The SME registration application approval cycle and the contributions per capita were obtained from the Internet and field questionnaires. The housing price income ratio was calculated according to the average price of commercial housing and the regional per capita income.

a. House Price to Income Ratio

$$
\begin{gathered}
H P I R={ }^{T P H} / T I F \\
T P H=R A P \times P P \times P H P \\
T I F=P P \times P T I
\end{gathered}
$$

HPIR is the house price to income ratio, TPH is the house price and TIF is the total annual household income. RAP is the residential housing area per capita, $P P$ is the household size, $P H P$ the average price per square meter, and PTI is the annual income per capita. 


\section{b Resource Abundance}

The ratio of mining employees to the total number of employees is used to characterize the regional resource abundance.

c Hydropower Supply Capacity

The water and electricity supply capacity of each region is measured by the satisfaction degree of the residents with the local water and electricity supply.

\section{d SME Registration Application Approval Cycle}

Due to the large difference in the actual situation of each region, there is a gap in the registration approval process, integrated services, network information platform construction, and the scale and type of small and medium-sized enterprises. In order to facilitate the data collection and enhance the comparability of the data, this paper measures the SME registration approval cycle from the perspective of the interviewees' satisfaction, and collects the receipt of the SME registration approval cycle in each region by issuing questionnaires.

\subsection{Results}

In this paper, ArcGIS software and the GTWR plug-in were used to carry out the spatial-temporal weighted regression of URD in Northeast China Shrinking Cities (NCSC).

(1) Results for SSA

The test results of LM, Hausman and LR for the non-spatial panel data are shown in Table 6.

Table 6. Non-spatial panel model test of URD in Northeast China.

\begin{tabular}{|c|c|c|c|}
\hline \multicolumn{2}{|c|}{ Test Estimator } & \multirow{2}{*}{$\begin{array}{c}\text { St } \\
22.73\end{array}$} & \multirow{2}{*}{$\frac{p \text {-Value }}{0.000}$} \\
\hline \multirow{4}{*}{ LM test } & LM (error); & & \\
\hline & Robust LM (error) & 26.47 & 0.001 \\
\hline & LM (lag) & 18.09 & 0.002 \\
\hline & Robust LM (lag) & 27.79 & 0.001 \\
\hline Hausman test & & 300.44 & 0.000 \\
\hline \multirow{2}{*}{ LR test } & Time fixed & 216.29 & 0.000 \\
\hline & Space fixed & 113.18 & 0.001 \\
\hline
\end{tabular}

As shown in Table 6, the Hausman test is significantly positive. Therefore, we rejected the null hypothesis and selected the fixed effect model. The joint significance test LR time-fixed and space-fixed test results are 216.29 and 113.18, respectively. Therefore, LM (error), Robust LM (error), LM (lag), and Robust LM (lag) test of the space and time dual fixed model were selected to verify the specific form of the model. The results showed that there are spatial lag effects of both variables and error terms. That is, SDM is suitable to conduct the SSA. Table 6 is the results of the SDM for SSA.

In Table 7, the Wald test spatial lag and Wald test spatial error statistics passed the $1 \%$ significance test. Therefore, SDM cannot degenerate into SAR or SEM. The total effect, direct effect and indirect effect of SDM are listed in Table 8.

The direct effect, the indirect effect and the total effect of the influencing factors on the shrinking cities are shown in Figure 4.

\section{a. The Direct Effect}

From the direct effect perspective, TIA, GML, EDL, EDQ, PSC, US, MCQ have positive influences on the URD of the shrinking cities. Notably, EDL and EDQ have the greatest positive effects on URD, reaching 0.501 and 0.469 , respectively. As we know, the development of EDL and EDQ requires the URD as the foundation. Therefore, it can be said that while URD promotes EDL and EDQ, economic development also has a significant role in promoting the URD. Besides this, the influence coefficient of TIA on URD is 0.401, 
revealing that technological innovation is an important motivation for attracting resource accumulation. In addition, GML can enhance the charm of cities and create a friendly environment for the entry of external resources. However, EL and HCD have no significant effect on the URD of the shrinking cities. This reflects that the natural environment and the human environment do not work on the URD of shrinking cities. It is worthy of noting that RE is the only factor that has a negative impact on the URD of the shrinking cities in Northeast China. The influence coefficient is -0.244 , and has passed the significance test of $1 \%$. It shows that the better the resource endowment is, the more unfavorable it will be to the URD, i.e., the "resource curse" proposed by relevant research [59].

Table 7. SDM model estimation results of both the time and space effects of URD.

\begin{tabular}{|c|c|c|}
\hline Factor & Time-Space Fixed & Time-Space Random \\
\hline TIA & $0.162^{* *}$ & $0.303^{* * *}$ \\
\hline GML & $0.335^{* * *}$ & $0.016^{*}$ \\
\hline EDL & $0.401 * * *$ & $0.461^{* * *}$ \\
\hline EDQ & $0.209 *$ & $0.502 * * *$ \\
\hline PSC & $0.109^{* * *}$ & $0.011 *$ \\
\hline US & $0.604^{* *}$ & $0.264^{* * *}$ \\
\hline EL & -0.024 & -0.059 \\
\hline RE & $0.337^{* * *}$ & $-0.107^{* *}$ \\
\hline $\mathrm{HCD}$ & 0.100 & $0.033^{* *}$ \\
\hline MCQ & 0.331 & $0.002 * *$ \\
\hline W*TIA & $-0.116^{* * *}$ & $0.373^{* *}$ \\
\hline $\mathrm{W}^{*} \mathrm{GML}$ & $-0.019^{* *}$ & $-0.062 *$ \\
\hline$W^{*}$ EDL & $0.503^{* *}$ & $-0.109 * * *$ \\
\hline$W^{*} E D Q$ & 0.011 & $-0.362 * * *$ \\
\hline W*PSC & $0.601^{* * *}$ & $0.001 *$ \\
\hline W*US & 1.247 & $-0.205^{* * *}$ \\
\hline$W^{*} E L$ & -0.289 & 0.322 \\
\hline$W^{*} \mathrm{RE}$ & $0.303^{* *}$ & $0.091 * *$ \\
\hline $\mathrm{W}^{*} \mathrm{HCD}$ & 0.609 & $0.102^{* * *}$ \\
\hline $\mathrm{W}^{*} \mathrm{MCQ}$ & 0.114 & $0.091^{* * *}$ \\
\hline R2 & 0.9195 & 0.9356 \\
\hline Adj-R2 & 0.9260 & 0.4001 \\
\hline Wald test spatial lag & $13.891^{* * *}$ & $215.339 * * *$ \\
\hline Wald test spatial error & $74.113 * * *$ & $108.772^{* * *}$ \\
\hline
\end{tabular}

$$
{ }^{*} p<0.1,{ }^{* *} p<0.05,{ }^{* * *} p<0.01
$$

Table 8. The total, direct and indirect effects of the SDM model of the URD of the shrinking cities in Northeast China.

\begin{tabular}{cccc}
\hline Factor & Direct Effect & Indirect Effect & Total Effect \\
\hline TIA & $0.401^{* * *}$ & $0.394^{*}$ & $0.795^{* * *}$ \\
GML & $0.202^{* *}$ & $-0.112^{* *}$ & $0.09^{* *}$ \\
EDL & $0.469^{* * *}$ & $-0.409^{* * *}$ & $0.06^{* * *}$ \\
EDQ & $0.501^{* * *}$ & $-0.497^{* *}$ & $0.004^{* * *}$ \\
PSC & $0.382^{* * *}$ & $-0.121^{* * *}$ & $0.503^{* * *}$ \\
US & $0.003^{* * *}$ & $-0.342^{* * *}$ & $0.345^{* *}$ \\
EL & $0.072^{* * *}$ & $0.101^{* *}$ & $0.173^{* *}$ \\
RE & $-0.244^{* * *}$ & $0.305^{* *}$ & $0.061^{* *}$ \\
HCD & $0.103^{*}$ & $0.007^{* *}$ & $0.11^{*}$ \\
\hline
\end{tabular}

b. The Indirect Effect

From the indirect effect perspective, TIA, El, RE and HCD have significant positive indirect effects on the URD of shrinking cities. In other words, they have spill-over effects 
on URD. As we can see, the indirect effect of TIA on URD is 0.394 , reflecting that the spill-over effects of technological innovation could improve the URD of the overall region. Instead, GML, EDL, EDQ, PSC and US have negative indirect effects on URD. That is, the negative spill-over effects of these factors would weaken the attraction of the shrinking cities for external resources, producing vicious competition.

\section{(2) Results for SHA}

In order to reveal the spatial heterogeneity of the factors' influences on the URD of the shrinking cities, GTWR is used to conduct the SHA. The results are shown in Figure 5.

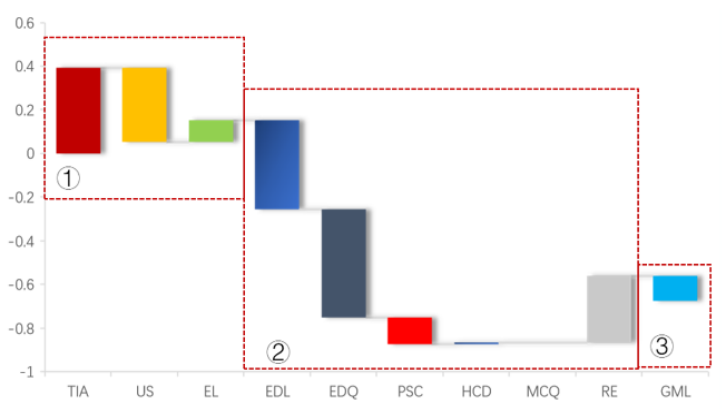

(a)

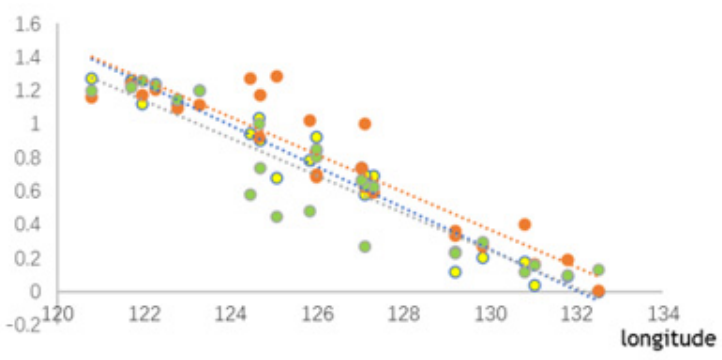

(c)

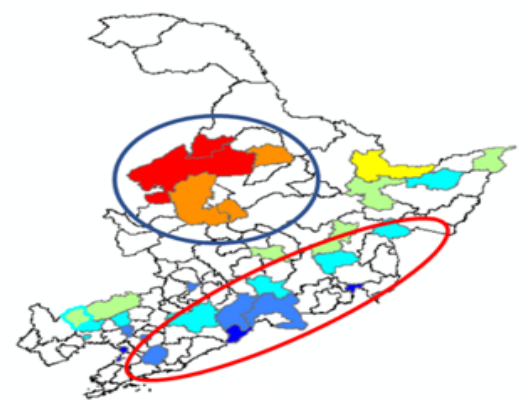

(b)

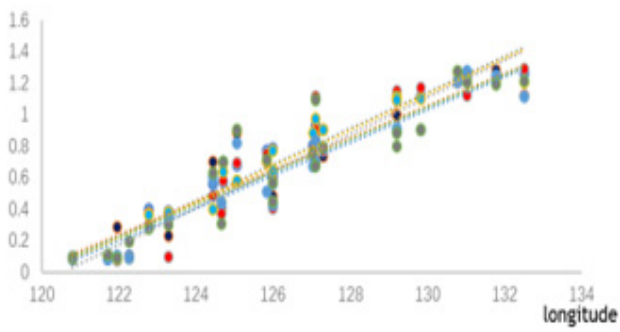

(d)

Figure 5. Influential factors and mechanisms of shrinking urban resources in Northeast China. (a) The coefficients of different factors. (b) The direct and indirect effects of GML. (c) The direct and indirect effects of TIA, US and EL. (d) The direct and indirect effects of EDL, EDQ, PSC, HCD, MCQ and RE.

Figure 4 illustrates the spatial heterogeneity of the influencing factors on the URD of the 24 shrinking cities in northeast China. The influence of TIA, US, EL on URD gradually weakens from the west to the east, and the coefficients are between 0.8 and 1.4 for the western cities such as Anshan, Fushun, Fuxin and Jinzhou. Instead, the influence of EDL, EDQ, PSC, HCD, MCQ and RE gradually strengthens from the west to the east, and the coefficients are between 1.0 to 1.4 for the URD of Hegang, Jiamusi, and Fujin. Notably, the influence of GML on the URD of the shrinking cities in Northeast China showed a trend of gradually increasing from the northwest to the southeast. The URDs of Qiqihar, Daqing, and Bei'an are influenced least. Anshan, Fushun, and Tonghua are the most affected, and the influence coefficient reaches more than 1.0.

\section{Discussion and Policy Implications}

From the above results of URD and the spatial spillover effect and spatial heterogeneity of various factors for the URD of the shrinking cities in Northeast China, the overall characteristics are summarized as shown in Figure 5.

From Figure 5, given the SSA and SHA, the influences can be categorized into three types: 
(1) The "High West + Low East and Negative-Positive Spillover" of TIA, US and EL. Most cities in Heilongjiang and Jilin are less affected by these factors, while Fuxin, Jinzhou, Anshan, Fushun and the other shrinking cities in Liaoning Province are strongly affected by these factors. Meanwhile, TIA and EL have a strong positive spillover effect, while US will produce a negative spillover effect. Therefore, these cities need to focus on improving the ability of technological innovation and environmental governance, and take reasonable measures to avoid disordered competition among cities.

(2) The "Low West and High East + Positive-Negative Spillover" of EDL, EDQ, PSC, HCD, MCQ and RE. Most shrinking cities in Jilin and Heilongjiang, such as Hegang, Jiamusi, Fujin, Ningan, and Jixi, etc., are affected by these factors. Meanwhile, EDL, EDQ, PSC have a negative spillover effect on the URD of shrinking cities. Therefore, while developing the urban economy and improving its governance service and management ability, it is also necessary to create reasonable planning and layout within the region to avoid disorderly competition. In contrast, HCD and RE could produce a positive spillover effect on the URD of the shrinking cities. Therefore, while enhancing the soft power of urban culture, the regional synergy of positive spillover of these factors should be focused on in order to achieve the comprehensive effect of " $1+1>2$ ".

(3) The "Low Northwest and High Southeast + Negative Spillover" of GML. A few shrinking cities in Liaoning, Jilin and Heilongjiang are influenced by GML significantly. For these cities, in the adjustment of the urban development strategy, it is necessary to focus on improving the level of government management. Considering the negative spillover, it is also necessary to do a good job in the regional overall development planning in order to avoid disordered competition.

From the above findings, we proposed the policy implications as follows:

(1) Strengthen competitive industries and implement urban transformation and upgrading. The imbalance of development is serious in and between the regions of Northeast China for the similarity of the development strategy, the decline of the resource advantage under the new era and economic transformation, and the constantly strengthened competition in and between these regions. It is necessary, under these circumstances, taking these regions and cities into the overall national and social development framework, to clarify the advantages and establish development strategies of their own from a higher level and a larger region.

(2) Strengthen the system design and optimize the regional urban arrangement. In order to change the unbalanced regional development in the northeast, the system guarantees of the government are needed, with system design as the driving force, carrying out macro planning and arrangements from the overall perspective of the region, promoting regional coordinated development.

(3) Increase investment in science and technology, and enhance the innovation capabilities. The innovation of science and technology is always the most efficient means to drive the development of a city, and the only way to achieve sustainable development and enhance the competitiveness of a city. The innovation ability of science and technology is always needed for the city, no matter the development of the economy, the optimization of the industrial structure, or the establishment of a social security system and the upgrading of the urban function carrier.

\section{Conclusion}

In order to reveal how the factors influence the shrinking cities in Northeast China from the perspective of equality, this paper established the URD model to measure the urban resource degree. Given the spillover effect and heterogeneity of the influencing factors, SDM and GTWR were used to conduct an empirical analysis of the URD of shrinking cities. The findings are summarized as follows: 
(1) In the study periods, the overall performance of the URD in Liaoning province is basically stable, with small fluctuation. Besides this, the URD of the six shrinking cities in Jilin Province has a short-term upward fluctuation, but the overall trend is downward. Notably, in the shrinking cities of Heilongjiang province, the URD of Daqing is far higher than that of other shrinking cities. On the contrary, Hegang's ability to compete for and control resources has declined sharply. Other cities have no drastic changes of the URD.

(2) The advantage of the URD of prefecture-level cities is gradually lost, and that of county-level cities is slightly improved. This reflects the fact that the ability gap to compete for and control resources between prefecture-level shrinking cities and county-level shrinking cities is narrowed.

(3) From the SSA and SHA perspectives, the influence factors can be categorized into three types, beginning with the "High West + Low East and Negative-Positive Spillover" of TIA, US and EL. Fuxin, Jinzhou, Anshan, Fushun and other shrinking cities in Liaoning Province are strongly affected by these factors. Next is the "Low West and High East + Positive-Negative Spillover" of EDL, EDQ, PSC, HCD, MCQ and RE. Hegang, Jiamusi, Fujin, Ningan, Jixi, etc are affected by these factors. Finally, there is the "Low Northwest and High Southeast + Negative Spillover" of GML. A few shrinking cities in Liaoning, Jilin and Heilongjiang are influenced by GML significantly.

From that above results, we proposed the policy implications from the perspectives of (1) strengthening competitive industries and implementing urban transformation and upgrading, (2) strengthening system design and optimizing regional urban arrangement, and (3) increasing investment in science and technology, and enhancing the innovation capabilities. URD indicates the resource endowment and the ability to compete with external resources of the shrinking cities. Therefore, it is indispensable to create reasonable planning and layout within the region in order to avoid disorderly development resulting from the negative spillover effect and make full use of the positive spillover effects of these factors to achieve the comprehensive effect of " $1+1>2$ ". We hope the findings can provide supports for related policy-making.

Author Contributions: Conceptualization, Y.W., J.G. and M.L.; methodology, Y.W. and J.G.; software, Y.W.; validation, Z.Z. and M.L.; formal analysis, Y.W. and M.L.; investigation, J.G.; resources, Y.W.; writing —original draft preparation, Y.W. and J.G.; writing—review and editing, J.G.; supervision, J.G. All authors have read and agreed to the published version of the manuscript.

Funding: This research has no external funding.

Institutional Review Board Statement: Not applicable.

Informed Consent Statement: Not applicable.

Data Availability Statement: Not applicable.

Acknowledgments: This research has been supported by the Science and Technology Research Program of Chongqing Municipal Education Commission (KJQN201801533, KJQN201801534).

Conflicts of Interest: The authors declare no conflict of interest.

\section{References}

1. Williamson, J.G. Coping with City Growth during the British Industrial Revolution: Did Britain's Cities Grow Too Fast? Cambridge University Press: Cambridge, UK, 1990.

2. GlennPorter. Encyclopedia of American Economic History: Studies of the Principal Movements and Ideas, 1st ed.; Charles Scribner's Sons: New York, NY, USA, 1980.

3. Jordan, E. Female unemployment in England and Wales 1851-1911: An examination of the census figures for 15-19 year olds. Soc. Hist. 1988, 13, 175-190. [CrossRef]

4. Li, Y. Encyclopedia of World City Knowledge; World Knowledge Pres: Tarkeshwar, India, 1985.

5. World Economic Research Office, Institute of Economics, Chinese Academy of Sciences. Economic Statistics of Major Capitalist Countries (1848-1960); World Knowledge Pres: Tarkeshwar, India, 1962. 
6. Zur Nedden, M. Leipzig—Eine wachsende Stadt in einem schrumpfenden Umland. Disp Plan. Rev. 2010, 46, 95-99. [CrossRef]

7. Seo, J.G. Study on the Cause and Strategic Approaches to Urban Decline and Shrinkage: Focusing on the case of Liverpool and Leipzig. J. Local Gov. Stud. 2014, 26, 97-115.

8. $\quad$ Lampen, A.; Owzar, A. Schrumpfende Städte; Böhlau Verlag: Weimar, Germany, 2008.

9. Liu, C. Comparative Research and Enlightenment of Shrinking Cities in China and Foreign Countries; Chongqing University: Chongqing, China, 2017.

10. Qian, F. Research on the New Trend of Urbanization Development in Hunan Province from the Perspective of "Shrinking City" Theory; Hunan University: Changsha, China, 2017.

11. Martinez-Fernandez, C.; Wu, C.T.; Schatz, L.K.; Taira, N.; Vargas-Hernández, J.G. The Shrinking Mining City: Urban Dynamics and Contested Territory. Int. J. Urban Reg. Res. 2012, 36, 245-260. [CrossRef] [PubMed]

12. Kotilainen, J.; Eisto, I.; Vatanen, E. Uncovering Mechanisms for Resilience: Strategies to Counter Shrinkage in a Peripheral City in Finland. Eur. Plan. Stud. 2015, 23, 53-68. [CrossRef]

13. Pallagst, K. Viewpoint: The planning research agenda: Shrinking cities-A challenge for planning cultures. Town Plan. Rev. 2010, 81, i-vi. [CrossRef]

14. Freixas, C.; Fernandez, P.I.M. Shrinking Cities: A Sustainability Assessment of Eco-Urbanism Strategies: The Mediated City Conference; Woodbury University: London, UK, 2014.

15. Camarda, D.; Rotondo, F.; Selicato, F. Strategies for Dealing with Urban Shrinkage: Issues and Scenarios in Taranto. Political Commun. 2015, 23, 126-146. [CrossRef]

16. Martinez-Fernandez, C.; Audirac, I.; Fol, S.; Cunningham-Sabot, E. Shrinking cities: Urban challenges of globalization. Int. J. Urban Reg. Res. 2012, 35, 213-225. [CrossRef]

17. Howe, S.R.; Bier, T.; Allor, D.; Finnerty, T.; Green, P. The shrinking central city amidst growing suburbs: Case studies of ohio's inelastic cities. Urban Geogr. 1998, 19, 714-734. [CrossRef]

18. Wiechmann, T.; Pallagst, K.M. Urban shrinkage in Germany and the USA: A Comparison of Transformation Patterns and Local Strategies. Int. J. Urban Reg. Res. 2012, 36, 261-280. [CrossRef]

19. Cortese, C.; Haase, A.; Grossmann, K.; Ticha, I. Governing Social Cohesion in Shrinking Cities: The Cases of Ostrava, Genoa and Leipzig. Eur. Plan. Stud. 2014, 22, 2050-2066. [CrossRef]

20. Guimarães, T.P.; Barreiraa, M.H. Influences on citizens policy preferences for shrinking cities: A case study of four Portuguese cities. Reg. Stud. Reg. Sci. 2015, 2, 140-169.

21. Guan, D.; He, X.; Hu, X. Quantitative identification and evolution trend simulation of shrinking cities at the county scale, China Sustain. Cities Soc. 2020, 65, 102611. [CrossRef]

22. Hollander, J.B.; Németh, J. The bounds of smart decline: A foundational theory for planning shrinking cities. Hous. Policy Debate 2011, 21, 349-367. [CrossRef]

23. Bontje, M. Facing the challenge of shrinking cities in East Germany: The case of Leipzig. Geojournal 2004, 61, 13-21. [CrossRef]

24. Haase, D.; Haase, A.; Rink, D. Conceptualizing the nexus between urban shrinkage and ecosystem services. Landsc. Urban Plan. 2014, 132, 159-169. [CrossRef]

25. Haase, A.; Rink, D.; Grossmann, K.; Bernt, M.; Mykhnenko, V. Conceptualizing urban shrinkage. Environ. Plan. A 2014, 46, 1519-1534. [CrossRef]

26. Bernt, M.; Haase, A.; Großmann, K.; Cocks, M.; Couch, C.; Cortese, C.; Krzysztofik, R. How does not Urban Shrinkage get onto the Agenda? Experiences from Leipzig, Liverpool, Genoa and Bytom. Int. J. Urban Reg. Res. 2014, 38, 1749-1766. [CrossRef]

27. Mallach, A.; Haase, A.; Hattori, K. The shrinking city in comparative perspective: Contrasting dynamics and responses to urban shrinkage. Cities 2017, 69, 102-108. [CrossRef]

28. Meng, X.; Jiang, Z.; Wang, X.; Long, Y. Shrinking cities on the globe: Evidence from LandScan 2000-2019. Environ. Plan. A-Econ. Space 2021. [CrossRef]

29. Kantor-Pietraga, I. Does One Decade of Urban Policy for the Shrinking City Make Visible Progress in Urban Re-Urbanization? A Case Study of Bytom, Poland. Sustainability 2021, 13, 4408.

30. Roak, M.; Hospers, G.J.; Reverda, N. Searching for Social Sustainability: The Case of the Shrinking City of Heerlen, The Netherlands. Sustainability 2016, 8, 382. [CrossRef]

31. Wichowska, A. Economic Aspects of Shrinking Cities in Poland in the Context of Regional Sustainable Development. Sustainability 2021, 13, 3104. [CrossRef]

32. Emmanuel, R.; Krüger, E. Urban heat island and its impact on climate change resilience in a shrinking city: The case of Glasgow, UK. Build. E Environ. 2012, 53, 137-149.

33. Liu, P.; Song, J. Research on the Application of Urban Competitiveness Evaluation in the New Urbanization of Beijing-TianjinHebei. J. Hebei Univ. Econ. Trade. 2019, 40, 70-77.

34. Wang, H.; Ni, P.; Gong, W.; Xu, H. Looking at the pattern, hierarchy and type of Chinese cities from a global perspective: A study based on global urban competitiveness data. J. Beijing Univ. Technol. Soc. Sci. Ed. 2019, 60-68.

35. Huang, G.; Liu, J.; Jiang, X.; Jia, G. Comparative research on the competitiveness of major cities at home and abroad based on complex network analysis methods. Urban Dev. Res. 2019, 26, 38-46.

36. Lei, L.; Song, W.; Bi, L. Can the dual innovation ecology affect the competitiveness of cities: Based on the inspection of potential niches. Forum Sci. Technol. China 2019, 273, 123-133. 
37. Liu, X.; Ni, P. Analysis on the Coupling Coordination Degree of Competitiveness of China's Large and Medium Cities. J. Hebei Univ. Econ. Bus. 2019, 40,57-64.

38. Dai, E. Analysis of sustainable development of urban park landscaping. Henan Build. Mater. 2019, $120-121$.

39. Han, G.Y.; Liu, X. Dynamic Early Warning of Urban Sustainable Development Based on Punishment Variable Weights: Taking Baotou, a resource-based city in Inner Mongolia, as an example. Stat. Inf. Forum 2019, 34, 83-93.

40. Cheng, G.; Chen, X. New Path of Sustainable Development: Environmental Regulation and Technological Progress: An Empirical Test Based on Threshold Effect. J. Anhui Norm. Univ. (Humanit. Soc. Sci. Ed.) 2019, 3, 69-77.

41. Wang, C.; Li, H.; He, Y. Sustainable development ability and its spatiotemporal differentiations of rural human settlements in Chongqing Municipality from 1997 to 2015. Prog. Geogr. 2019. [CrossRef]

42. Du, K.; Zhang, N. Resource Abundance and Ecological Efficiency of Chinese Cities: An Empirical Analysis Based on Conditional SBM Model. J. Xi'an Jiaotong Univ. Soc. Sci. Ed. 2019, 39, 65-72.

43. Chen, Y.; Liu, J. Urban spatial cross-correlation and power spectrum analysis based on gravity model-Theoretical proof, function promotion and application examples of gravity model. Geogr. Res. 2002, 21, 742-752.

44. Zhang, C.; Qian, Y.; Zeng, J. Analysis on the construction and development of the same urbanization in Lanxi area. Railw. Transp. Econ. 2019, 41, 27-32.

45. Wang, S.; Song, Y.; Wen, H. The network structure of urban agglomerations in the Yangtze River Economic Belt from the perspective of two-way connections: Based on time distance and social network analysis methods. Econ. Geogr. 2019, 39, 73-81.

46. Liang, $\mathrm{H}$. The spatial network structure and operational effects of the development of the logistics industry in the five major urban agglomerations in my country. China Circ. Econ. 2019, 33, 52-63.

47. Miao, H.; Zhou, H. Analysis of the characteristics of the internal urban network connections of the three major urban agglomerations in China: Comparison and enlightenment. J. Panzhihua Univ. Compr. Ed. 2019, 36, 47-54.

48. Wang, D.; Lv, Y. Does distance affect the undertaking effect of service outsourcing business. Macroecon. Res. 2019, 242, 87-100.

49. Zhu, R.; Ouyang, J.; He, J. Analysis on the Potential of Sino-Fiji Bilateral Agricultural Products Trade. J. Yunnan Agric. Univ. (Soc. Sci.) 2019, 13, 86-94.

50. Qiao, Y. Research on China's Vegetable Export Trade and International Competitiveness. Price Mon. 2019, 40-46.

51. Wang, F.; Tian, Y.; Cheng, B. Research on the Export Trade of Agricultural Products between China and Countries along the 21st Century Maritime Silk Road. Int. Econ. Coop. 2019, 80-90.

52. Wiechmann, T. Errors Expected-Aligning Urban Strategy with Demographic Uncertainty in Shrinking Cities. Int. Plan. Stud. 2008, 13, 431-446. [CrossRef]

53. D' Hooghe, A. Field Guide to Sprawlby Dolores Hayden. AA Files 2007, 53, 74-78.

54. Zhang, X.; Liu, Y.; Lu, C. Analysis of the background, recognition and characteristics of China's urban shrinkage. J. Southeast Univ. (Philos. Soc. Sci. Ed.) 2016, 18, 132-139.

55. Mao, Q.; Long, Y.; Wu, K. A preliminary study on the temporal and spatial evolution of population density and the spatial pattern of urbanization in China: From 2000 to 2010. Urban Plan. 2015, 39, 38-43.

56. Zhang, W.; Shan, F.; Zheng, C.; Hu, R. Multi-dimensional identification of urban shrinkage in my country and analysis of its driving mechanism. Urban Dev. Res. 2019, 32-40.

57. Multi-dimensional, Multi-scale Quantitative Identification and Causes of Urban Shrinkage: A Case Study of Northeast China during the Transition Period. Mod. City Res. 2018, 37-46.

58. Wu, K. The Cognitive Misunderstanding of Urban Shrinkage and the Response of Spatial Planning. Beijing Plan. Constr. 2019, 4-11.

59. Shao, S.; Yang, L. Natural resource dependence, human capital accumulation, and economic growth: A combined explanation for the resource curse and the resource blessing. Energy Policy 2014, 74, 632-642. [CrossRef] 